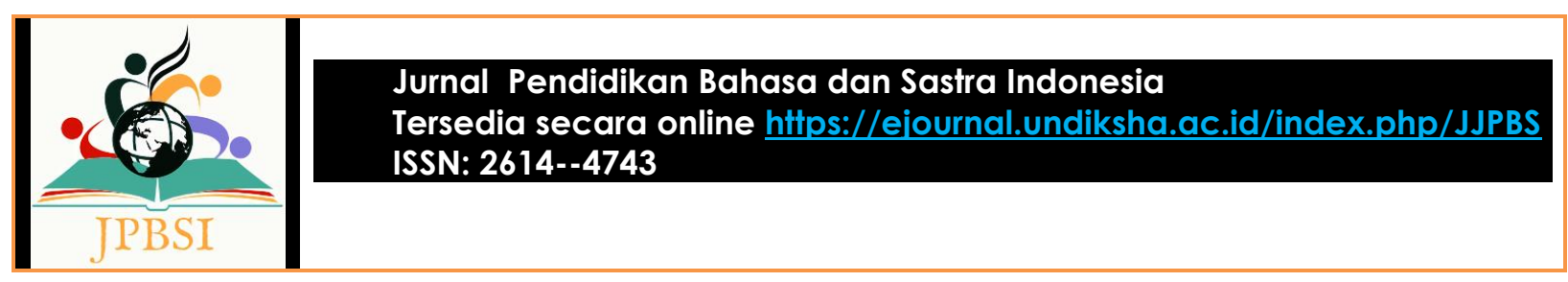

\title{
ANALISIS KESALAHAN BAHASA IKLAN DI KOTA JAKARTA UTARA DAN RELEVANSINYA SEBAGAI BAHAN AJAR SMP
}

\author{
Dhiya Ulhaq ${ }^{1}$, Oding Supriadi ${ }^{2}$, Dian Hartati ${ }^{3}$ \\ 1,2,3 Program Studi Pendidikan Bahasa dan Sastra Indoesia, Universitas Singaperbangsa Karawang \\ Kerawang, Jawab Barat, Indonesia
}

Surel:1710631080046@student.unsika.ac.id',odingsupr17@gmail.com²,ragambacaan@gmail.com ${ }^{3}$

\begin{tabular}{|c|c|}
\hline \multicolumn{2}{|r|}{ Abstrak } \\
\hline $\begin{array}{ll}\text { Kata Kunci: } & \text { Analisis } \\
\text { Kesalahan } & \text { Bahasa; } \\
\text { Bahan Ajar; Teks Iklan }\end{array}$ & $\begin{array}{l}\text { Penelitian ini bertujuan untuk mendeskripsikan kesalahan berbahasa dalam teks iklan } \\
\text { yang terdapat di Kota Jakarta Utara, menganalisis urutan kata atau frasa pada setiap } \\
\text { data teks iklan dan menelaah makna, serta menganalisis urutan kalimat untuk } \\
\text { mengetahui fungsi SPOK serta unsur fungsi dari bahasa yang ditemukan dari analisis } \\
\text { kesalahan berbahasa.Objek penelitian adalah kesalahan berbahasa dengan menemukan } \\
\text { frasa, klausa, dan fungsi bahasa pada teks iklan di Kota Jakarta Utara. Metode yang } \\
\text { digunakan untuk mengumpulkan data adalah metode dokumentasi dan simak. Hasil } \\
\text { penelitian ini menunjukkan bahwa analisis temuan kesalahan berbahasa teks iklan } \\
\text { produk dan jasa di Kota Jakarta Utara yang menghasilkan laras bahasa terdapat } 10 \text { data } \\
\text { dokumentasi, dan } 1 \text { laras bahasa perniagaan, frasa yang ditemukan terdapat } 10 \text { pada } \\
\text { analisis kesalahan berbahasa, ditemukan terdapat } 6 \text { klausa dan } 4 \text { fungsi direktif, } 8 \text { fungsi } \\
\text { informatif, } 4 \text { fungsi interaksional, } 1 \text { fungsi puitik. }\end{array}$ \\
\hline \multicolumn{2}{|r|}{ Abstract } \\
\hline $\begin{array}{l}\text { Keywords: Language } \\
\text { Error Analysis; } \\
\text { Teaching Materials; } \\
\text { Ad Text. }\end{array}$ & $\begin{array}{l}\text { This study aims to describe language errors in advertising texts in North Jakarta City, } \\
\text { there is a sequence of words or phrases in each ad text data and states its meaning, } \\
\text { there is a sequence of sentences to determine the SPOK function, the functional } \\
\text { elements of the language found from the analysis of language errors. The object of the } \\
\text { research is language errors by finding phrases, clauses, and language functions in } \\
\text { advertising texts in North Jakarta City. The method used to collect data is the } \\
\text { documentation and referencing method. The results of this study indicate that the } \\
\text { analysis of finding errors in the language of the text of product and service } \\
\text { advertisements in the city of North Jakarta which produces the language barrel } \\
\text { contains } 10 \text { documentation data, and } 1 \text { commercial language barrel. There are } 10 \\
\text { phrases found in the analysis of language errors, there are } 6 \text { clauses and } 4 \text { directive } \\
\text { functions, } 8 \text { informative functions, } 4 \text { interactional functions, } 1 \text { poetic function. }\end{array}$ \\
\hline $\begin{array}{l}\text { Diterima/direview/ } \\
\text { dipublikasi }\end{array}$ & ustus $2021 / 30 \mathrm{~S}$ \\
\hline
\end{tabular}

PENDAHULUAN

Peningkatan penggunaan iklan luar ruang dari hari ke hari memicu terjadinya variasi penggunaan bahasa dan variasi pemenuhan kebutuhan yang telah dilakukan oleh masyarakat. Media cetak luar ruang di Kota Jakarta Utara merupakan media yang mudah ditemukan oleh seluruh lapisan masyarakat khususnya dari Wilayah Kota Jakarta Utara karena dianggap lebih praktis guna pemenuhan kebutuhan tersebut. Teks iklan yang digunakan dalam penulisan iklan tersebut banyak terdapat ketidaksesuaian dengan pemakainya. Bahasa yang digunakan dalam teks iklan produk dan jasa harus memunculkan ketertarikan pada pembaca melalui kosakata maupun kalimat yang sesuai dalam konteks iklan itu sendiri. Penelitian ini mengenai laras bahasa yang terdapat dalam teks iklan produk dan jasa penting diteliti untuk mengetahui perkembangan bahasa yang digunakan dan bagaimana penulis atau pembuat iklan tersebut menggunakan bahasa dalam iklan yang baik. Hal tersebut berkaitan dengan 


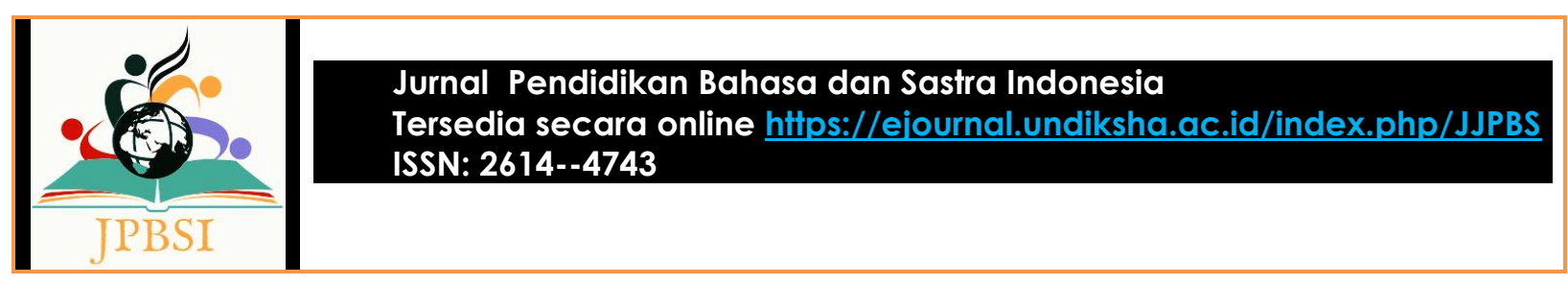

kesesuaian antara bahasa yang digunakan dengan hal-hal yang menjadi pembahasa dalam teks iklan yang dibuat.

Penelitian ini dimaksudkan untuk menganalisis kesalahan berbahasa Indonesia pada penulisan iklan media luar ruang di Kota Jakarta Utara. Dengan objek penelitiannya yaitu spanduk, papan nama pertokoan, baliho, papan nama instansi yang terdapat pada wilayah Kota Jakarta Utara. Media luar ruang di wilayah kota Jakarta Utara memiliki karakteristik yang unik dan menarik dan hal tersebut bisa dijadikan sebagai data penelitian adalah yang pertama, media luar ruang seperti spanduk, baliho dan papan nama lebih mudah ditemukan dibandingkan dengan penemuan pada media elektronik. Kedua, rentang waktu pemasangannya dapat dikatakan lebih lama sesuai dengan prosedur yang dilakukan. Ketiga, media luar ruang mampu menjangkau seluruh lapisan masyarakat. Keempat, penelitian terhadap media luar ruang di wilayah Kota Jakarta Utara sejauh pengetahuan peneliti belum pernah dilakukan.

Untuk memecahkan permasalahan terdapat beberapa identifikasi pentingnya melakukan penelitian ini yaitu kesalahan berbahasa bisa dilakukan terus menerus, adanya kekeliruan setiap orang dalam menggunakan Bahasa Indonesia yang baik. Masalah yang akan terpecahkan dengan adanya penelitian ini yaitu bentuk kesalahan berbahasa berupa urutan kata, struktur kalimat dan fungsi dari penemuan setiap kesalahan berbahasa sehingga menjadi laras bahasa yang sesua antara bahasa dan penggunaannya.

Manfaat dari penelitian ini adalah hasil yang akan didapat dari penelitian ini dapat diharapkan untuk memberikan tambahan suatu wawasan pengetahuan mengenai kesalahan penggunaan kebahasaan, khususnya pada penggunaan bahasa pada iklan media luar ruang. Penelitian ini dapat diharapkan juga untuk memberikan suatu pemahaman terhadap pemakaian atau penggunaan bahasa yang baik dalam penulisan iklan luar ruang, terutama dalam memahami suatu penggunaan bahasa. Penelitian ini juga melampirkan sebuah implikasi pada pembelajaran Bahasa Indonesia dengan materi teks iklan di kelas VIII yang dapat diharapkan dapat menambah wawasan dan membantu proses belajar mengajar Bahasa Indonesia khususnya di Kota Jakarta Utara. Penelitian ini diperlukan agara suatu iklan luar ruang tidak dibuat semata-mata hanya memberikan sebuah informasi kepada seluruh lapisan masyarakat namun juga berperan penting dalam memberikan ilmu yang bermanfaat kepada masyarakat. Dan dapat juga digunakan untuk meningkatkan perbaikan kesalahan berbahasa tepatnya pada penggunaan dan kesadaran untuk berbahasa yang baik dan benar sehingga sesuai.

\section{METODE PENELITIAN}

Penelitian ini menggunakan metode kualitatif, dengan menggunakan pendekatan deksriptif, untuk membuat pecandraan secara sistematis, faktual, dan akurat mengenai fakta-fakta dan sifat-sifat atau daerah tertentu. Penggunaan pendekataan tersebut untuk memperoleh deskripsi secara faktual yang sedang berlangsung pada masa sekarang, atau pada masa penelitian dilaksanakan. Data pada penelitian ini dikumpulkan atau memulai terjun ke lapangan pada awal bulan Mei sampai bulan Juni. Iklan media luar ruang yang terdapat di Kota Jakarta Utara yaitu kecamatan tanjung priuk, kecamatan koja, kecamatan cilincing, kecamatan kelapa gading.

Tempat penelitian ini berada di wilayah Kota Jakarta Utara, yang pada umumnya terdapat banyak dijumpai kesalahan berbahasa pada penulisan iklan media luar ruang. Dan dalam penelitian ini, metode deskriptif yang digunakan bertujuan untuk mengetahui serta mendeskripsikan bagaimana penggunaan atau bagaimana cara menganalisis sebuah kesalahan berbahasa ragam tulis pada media ruang luar. Sumber data yang digunakan pada penelitian Menurut Lofland dalam Moleon (2006: 157) dapat dijelaskan bahwa data primer merupakan data yang dikumpulkan atau diperoleh langsung oleh peneliti yang bersumber dari lapangan langsung.

Metode analisis pada penelitian ini menggunakan teknik dokumentasi. Menurut Sugiyono (2013: 240) mengatakan teknik dokumentasi merupakan suatu kegiatan catatan peristiwa yang sudah 


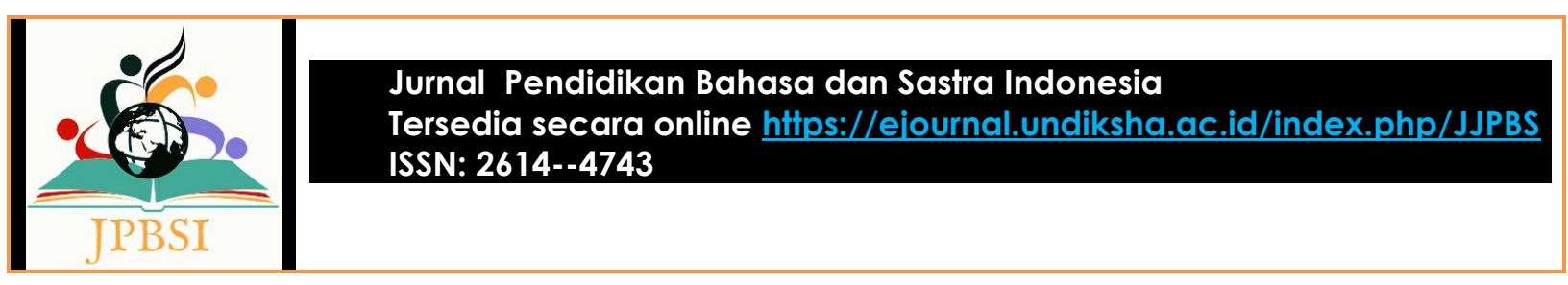

berlalu. Yang artinya dokumen tersebut dapat berbentuk tulisan, gambar, atau karya yang memiliki makna dan maksud tujuan dari pembuatannya. Menurut Arikunto (2007: 101) instrument penelitian merupakan sebuah alat bantu yang telah dipilih dan dipergunakan oleh peneliti dalam kegiatan penelitian mengumpulkan data agar penelitian diatur dengan cara yang baik dan dipermudah pelaksanaannya.

Adapun teknik pengumpulan data yang dilakukan adalah sebagai berikut, pertama yaitu dengan melakukan studi pustaka, yaitu dapat dilakukan yang semata-mata untuk mendapatkan keterangan yang menyeluruh atau sempurna mengenai kesalahan berbahasa ragam tulisan. Sumber berasal dari buku mata kuliah kebahasaan, artikel dan jurnal penelitian dan yang bersangkutan dengan pendidikan, karya ilmiah dan halaman web. Selanjutnya, tahap melakukan observasi dilakukan dengan cara pengamatan secara langsung mengenai data apa yang akan diambil dan dijadikan sampel penelitian atau untuk dapat mengumpulkan data penelitian dengan cara melakukan dokumentasi menggunakan gawai, yaitu dapat dilakukan dengan cara merekam, mengambil gambar iklan dan mencatat data-data yang diperoleh dari hasil observasi atau pengamatan langsung.

Menurut Miles dan Huberman (dalam Sugiyono, 2007) mengatakan bahwa suatu aktivitas yang terdapat dalam analisis data kualitatif dapat dilakukan secara interaktif dan berlangsung secara terus menerus sampai tuntas, sehingga data yang diperoleh atau setelah tidak ada data yang dianggap baru atau jenuh. Teknik analisis data terdiri atas tiga kegiatan yaitu, reduksi data. Penyajian data dan yang terakhir yaitu penarikan kesimpulan. Teknik analisis data dengan menggunakan teknik bagi unsur langsung dengan cara membagi beberapa kalimat pada paragraph agar tidak terdapat kalimat yang ambigu atau memiliki dua makna, dan dapat dipahami oleh pembaca iklan media luar ruang tersebut.

\section{HASIL DAN PEMBAHASAN}

Daily Wash (D11/20/Mei/21)

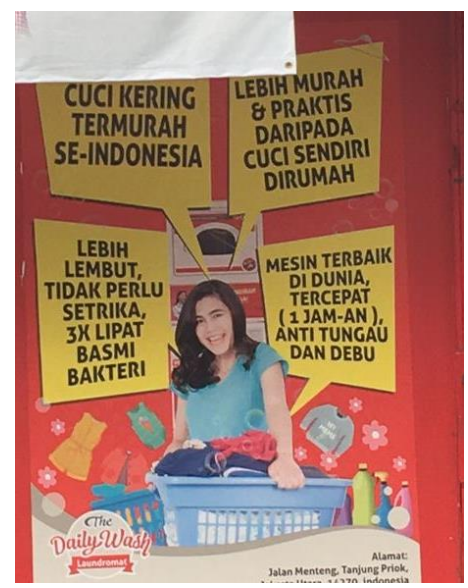

Gambar 1. Iklan Daily Wash

Kalimat pada data di atas dapat dibagi menjadi empat unsur, yaitu (a) cuci kering termurah seIndonesia, (b) lebih murah dan praktis daripada cuci sendiri di rumah, (c) lebih lembut tidak perlu setrika, tiga kali lipat basmi bakteri, (d) mesin terbaik di dunia, satu jam anti tungai dan debu. Pembagian unsur dengan menggunakan teknik bagi unsur langsung tersebut dapat dibagi menjadi empat bagian neserta dengan maknanya, yaitu: (a) cuci kering termurah se-Indonesia, bermakna bahwa palayanan jasa laundry ditempat tersebut merupakan tempat laundry termurah di Indonesia kalimat tersebut memasuki fungsi direktif seakan mengajak pembaca untuk melakukan sebuah tindakan yaitu laundry di tempat tersebut, (b) lebih murah dan praktis daripada cuci sendiri di rumah, bermakna bahwa laundry di tempat tersebut lebih murah daripada laundry di tempat lain, dan praktis atau hemat waktu dan tenaga daripada cuci sendiri di rumah, (c) lebih lebut tidak perlu setrika, bermakna bahwa laundry 


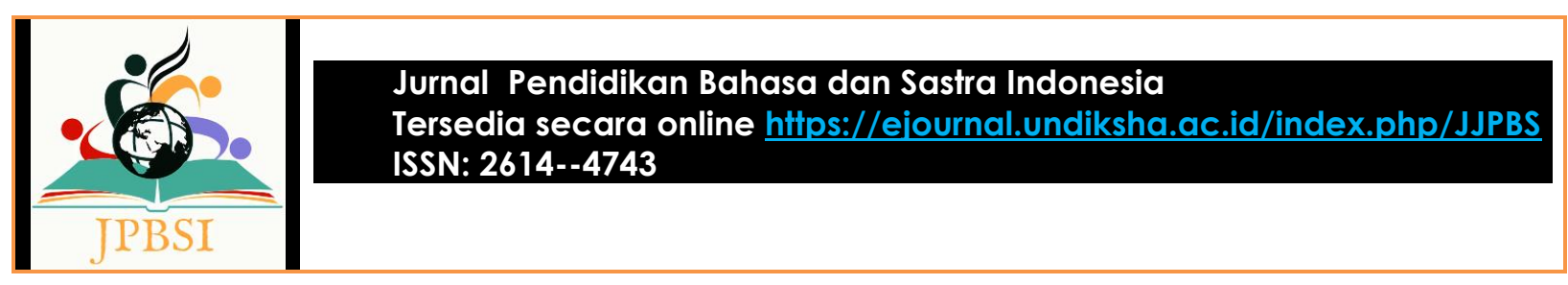

di tempat tersebut memiliki alat yang lebih praktis dan cepat kerjanya daripada menggunakan setrika atau tidak membuang waktu, (d) mesin terbaik di dunia, satu jam anti tungau dan debu, bermakna bahwa laundry di tempat tersebut menggunakan mesin terbaik yang terdapat di dunia, dalam pengerjaan satu jam dapat membunuh tungau dan menghilangkan debu pada pakaian.

\section{Ozi Salon (D12/21/Mei/21)}

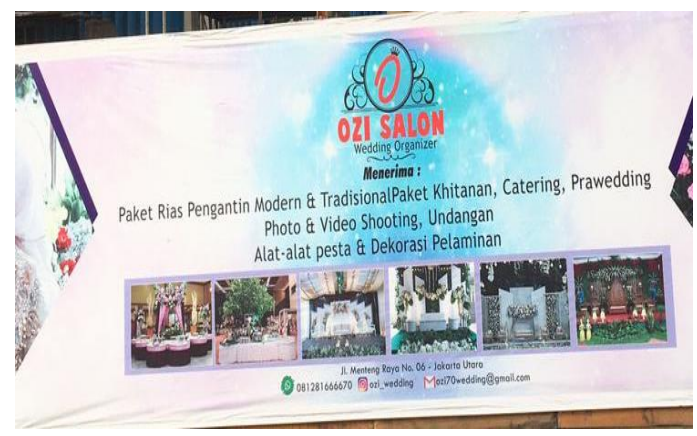

Gambar 2. Iklan Ozi Salon

Kalimat pada data teks iklan di atas dapat dibagi menjadi empat unsur, yaitu: (a) paket rias pengantin modern dan tradisional, (b) paket khitanan, catering, prawedding, (c) photo dan video shooting, undangan, (d) alat-alat pestra dan dekorasi pelaminan. Dengan menggunakan teknik bagi unsur langsung pada kalimat teks iklan tersebut dapat dibagi menjadi empat bagian berikut dengan maknanya, yaitu: (a) paket rias pengantin modern dan tradisional, bermakna bahwa palayanan jasa di Ozi salon menerima pelayanan untuk merias pengantin dengan model terbaru dengan penampilan gaya modern atau yang lebih masa kini, dan juga menerima pelayanan untuk merias pengantin dengan model tradisional sesuai dengan suku, adat istiadat pakaian daerah masing-masing pengantin, (b) paket khitanan, catering, prawedding, bermakna bahwa pelayanan jasa di Ozi salon tidak hanya menyediakan paket untk rias pengantin, akan tetapi terdapat paket khitanan yaitu sunnatan untuk anak laki-laki, selain itu ada paket catering yaitu makanan untuk dihidangkan kepada tamu undangan, dan prawedding, yaitu paket untuk photo yang akan dipajang ketika acara pernikahan kelak, untuk mempermanis suasana, (c) photo dan video shooting, undangan, bermakna bahwa layanan jasa tersebut menyediakan kamera dengan photograpernya untuk photo dan video shooting yang akan dijadikan sebagai kenangan dengan mengingat hal manis kepada pelanggan, (d) alat-alat pesta dan dekorasi pelaminan, berarti layanan jasa tersebut menyediakan alat-alat pesta seperti tempat makan para tamu, dekorasi pelaminan seperti bangku, tempat untuk menyimpan uang atau buah tangan dari tamu, bunga untuk dekorasi papan pelaminan, dan lain sebagainya. Jadi, pembagian unsur langsung pada kalimat teks iklan di atas bermaksud untuk memberikan pemahaman kepada pembaca bahwa Ozi salon merupakan tempat pelayanan jasa dengan palanan lengkap, ad arias pengantin, khitanan, dan photo dan video shooting, sehingga pembaca dapat memilih sesuai kebutuhannya dengan paket yang disediakan oleh Ozi salon. Kalimat teks iklan di atas merupakan teks iklan jasa dan termasuk jenis laras bahasa perniagaan.

\section{Ultraproof (D13/22/Mei/21)}

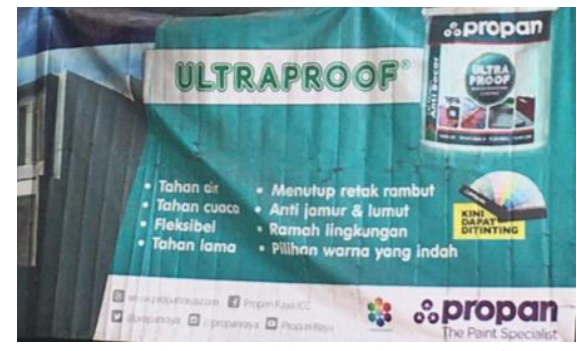

Gambar 3. Iklan Ultraproof 


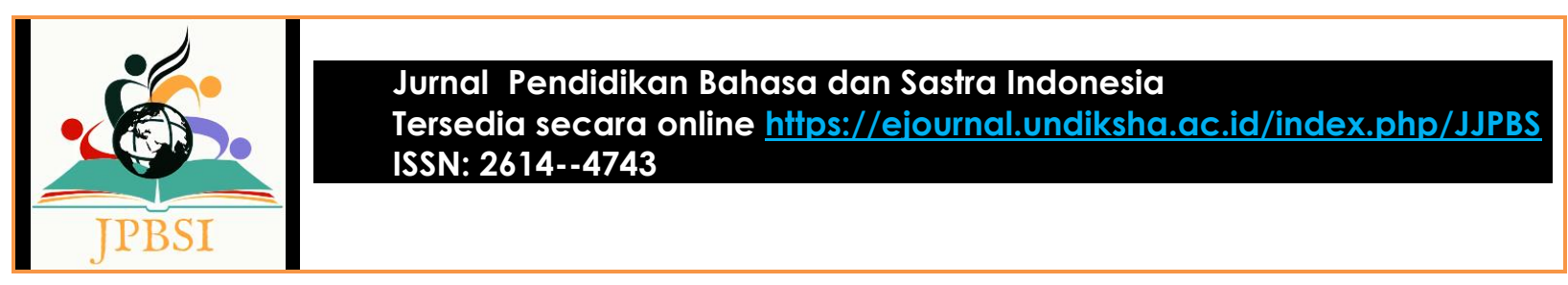

Kalimat teks iklan dari data di atas dapat dibagi menjadi lima unsur, yaitu: (a) ultraproof, tahan air, tahan cuaca, tahan lama, fleksibel, (b) menutup retak rambut, (c) anti jamur dan lumut, (d) ramah lingkungan, (e) pilihan warna yang indah. Pembagian unsur langsung dari teks iklan spanduk tersebut terdapat lima bagian, yaitu: (a) ultraproof, tahan air, tahan cuaca, tahan lama, fleksibel, yang bermakna bahwa ultraproof bisa tahan apa saja yaitu tahan air maksudnya yaitu tembok tidak rembes atau bocor jika cuaca sedang hujan, tahan cuaca yang berarti cat tembok tersebut tidak akan rusak baik cuaca sedang kemarau yang akan menyebabkan menghilangnya warna cat tembok dan cuaca sedang hujan tidak akan bocor air hujannya, tahan lama berarti cat tembok tersebut warnanya tidak akan pudar, fleksibel yang berarti cat tembok tersebut dapat menyesuaikan pada cuaca, (b) menutup retak rambut, bermakna bahwa cat tembok tersebut dapat menutupi retak cat tembok sebelumnya, (c) anti jamur dan lumut, bermakna bahwa cat tembok tersebut sudah dipastikan tidak aka nada jamur dan lumut yang menempel karena pada saat hujan tidak terjadi kebocoran sehingga menyebabkan tembok menjadi lembab, (d) ramah lingkungan, bermakna bahwa tidak akan membahayakan lingkungan sekitar, (e) pilihan warna yang indah, bermakna bahwa terdapat beberapa varian warna dari cat tembok tersebut warna yang bagus dan indah untuk dipandang. Jadi, pembagian unsur langsung pada kalimat data teks iklan tersebut bertujuan untuk memberikan pengetahuan atau pemahaman kepada pembaca bahwa produk cat tembok tersebut memiliki banyak kelebihan dan manfaat. Kalimat teks iklan di atas merupakan jenis laras bahasa perniagaan.

\section{Jotun Majestic (D14/23/Mei/21)}

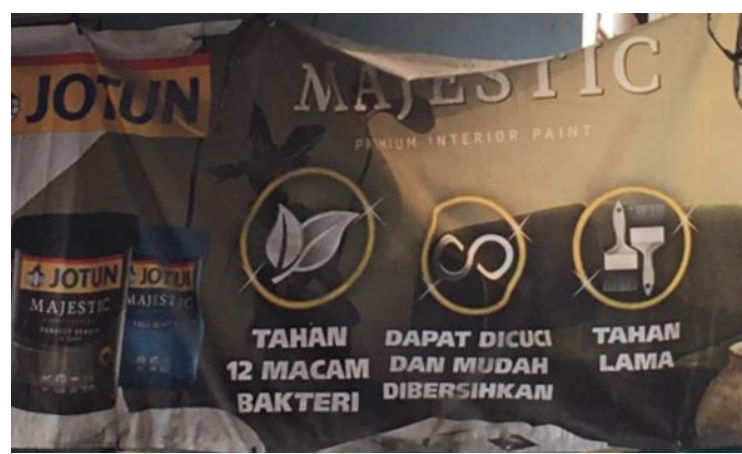

Gambar 4. Iklan Jotun Majestic

Pada kalimat teks iklan di atas dapat dibagi menjadi tiga unsur, yakni: (a) tahan 12 macam bakteri, (b) dapat dicuci dan mudah dibersihkan, (c) tahan lama. Kalimat tersbut tidak bisa dibagi menjadi (a) tahan 12 macam bakteri dapat, (b) dicuci dan, (c) mudah dibersihkan tahan lama. Pembagian dengan menggunakan teknik bagi unsur langsung pada kalimat tersebut dibagi menjadi tiga bagian, yaitu: (a) tahan 12 macam bakteri, bermakna bahwa dengan menggunakan cat tembok tersebut maka keuntungannya yaitu dapat dengan mudah untuk tahan 12 macam bakteri dan akan memberikan pemahaman bagi pembaca bahwa cat tersebut aman bagi kesehatan, (b) dapat dicuci dan mudah dibersihkan, bermakna bahwa cat tembok jotun dapat dengan mudah dicuci dan dibersihkan ketika terdapat kotoran berupa cairan-cairan tertentu dan coretan tembok yang biasanya dilakukan denan anakanak, tahan 12 macam bakteri, (c) tahan lama, bermakna bahwa tahan lama yang dimaksud pada teks tersebut yaitu warna yang tahan lama tidak akan pudar yang disebabkan oleh cuaca dan lain sebagainya. Jadi, pembagian unsur langsung tersebut bermaksud untuk memberikan pemahaman lebih khusus mengenai manfaat dan kegunaan cat tembok tersebut, bahwa ada cat tembok yang tahan lama dan dapat dicuci dan mudah dibersihkan kemudian dapat juga tahan 12 macam bakteri. 


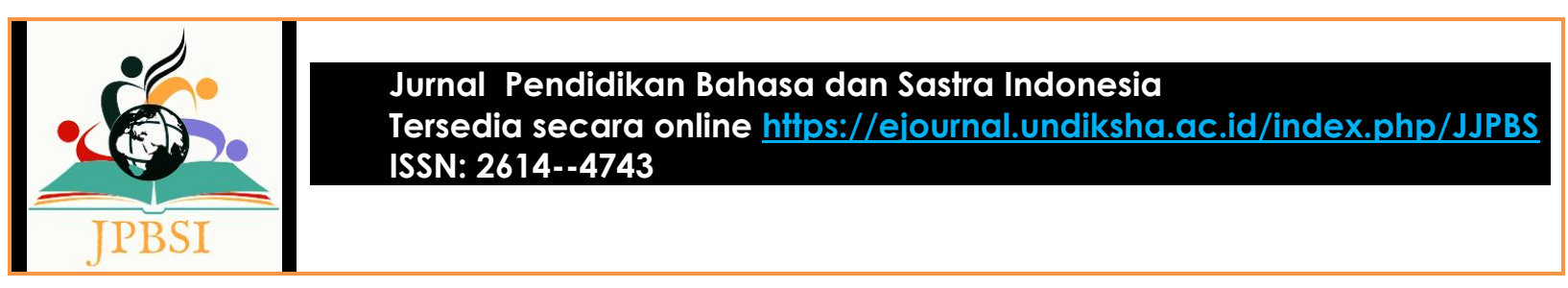

Oli Castrol (D15/24/Mei/21)

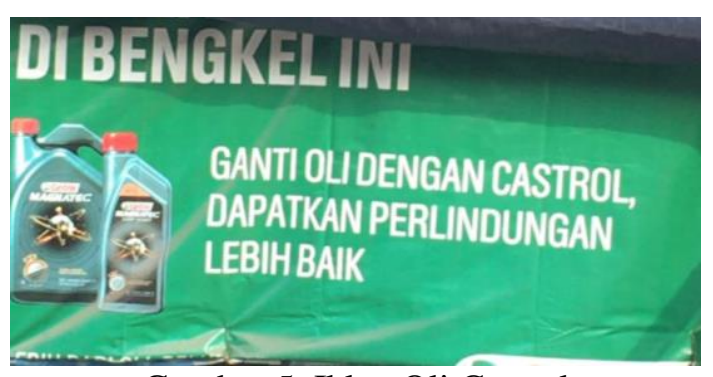

Gambar 5. Iklan Oli Castrol

Kalimat pada data teks iklan di atas dapat dibagi menjadi dua unsur, yakni: (a) di bengkel ini, ganti oli dengan Castrol, (b) dapatkan perlindungan lebih baik. Kalimat tersebut tida bisa dibagi menjadi: (a) di bengkel ini, ganti oli, (b) dengan Castrol dapatkan perlindungan lebih baik.

Pembagian kalimat data teks iklan tersebut dapat dibagi menjadi dua bagian, yaitu: (a) di bengkel ini, ganti oli dengan Castrol, bermakna bahwa di bengkel tersebut pelanggan bisa meminta untuk olinya diganti dengan oli Castrol atau bengkel tersebut dapat melayani pelanggan yang ingin mengganti oli dengan oli Castrol, (b) dapatkan perlindungan lebih baik, berarti dengan mengganti dengan oli Castrol akan mendapatkan perlindungan yang lebih baik daripada menggunakan merek oli lainnya. Jadi, pembagian unsur langsung tersebut bermaksud untuk memberikan informasi kepada pembaca bahwa bengkel tersebut dapat melayani pergantian oli dengan menggunakan olis Castrol dengan manfaat mendapatkan perlindungan lebih baik.

\section{Semen Tiga Roda (D16/25/Mei/21)}

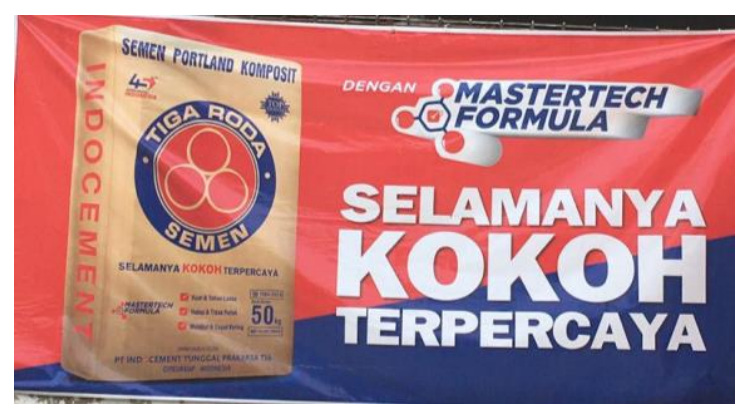

Gambar. 6 Iklan Semen Tiga Roda

Kalimat pada data teks iklan di atas dapat dibagi menjadi dua unsur, yakni: (a) semen tiga roda (b) selamanya kokoh dan terpercaya. Kalimat tersebut tidak bisa dibagi menjadi (a) semen tigaroda selamanya, (b) kokoh terpercaya. Pembagian unsur langsung dengan menggunakan teknik bagi unsul langsung (BUL) pada kalimat teks iklan spanduk tersebut dibagi menjadi dua bagian, yaitu: (a) semen tiga roda, yang berarti nama produk tersebut menamai produknya dengan semen tiga roda, (b) selamanya kokoh dan terpercaya, yang berarti dengan menggunakan produk tersebut bangunan rumah akan selamanya kokoh dan produk tersebut dapat dipercaya dari bahan dan manfaatnya. Jadi, pembagian unsur langsung pada kalimat data teks iklan tersebut bertujuan untuk memberikan penjelasan kepada pembaca bahwa semen tiga roda akan membuat bangunan menjadi kokoh selamanya dan terpercaya. Kalimat diatas merupakan teks iklan produk dan memasuki jenis laras bahasa perniagaan. 


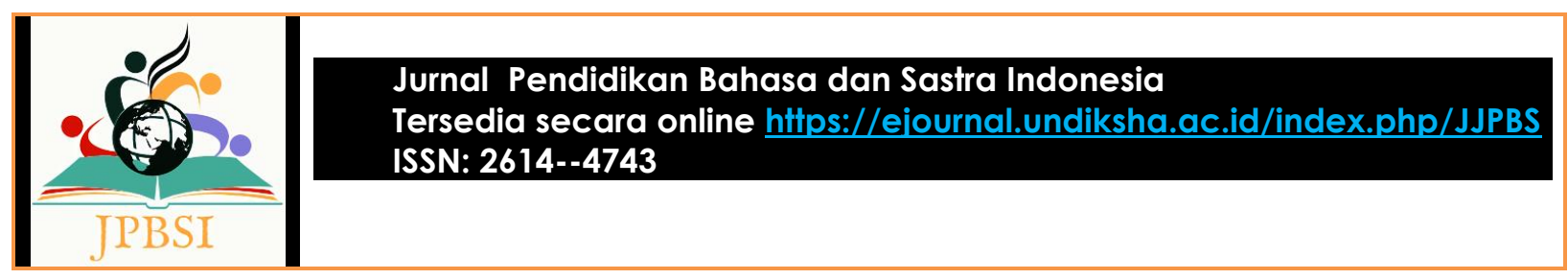

AHM Oil (D17/26/Mei/21)

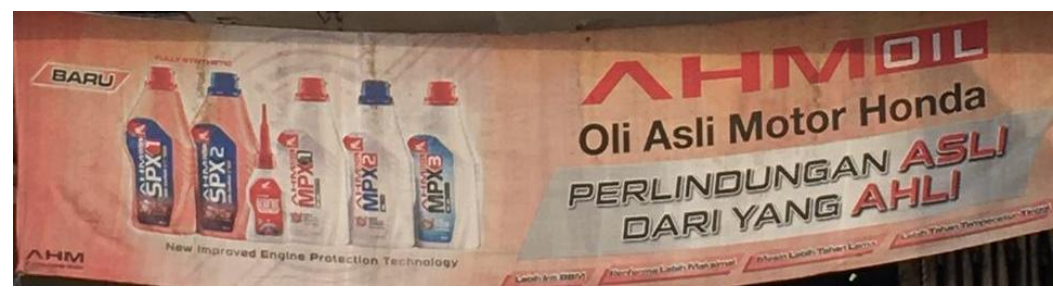

Gambar 7. Iklan AHM Oil.

Kalimat pada data teks iklan di atas dapat dibagi menjadi dua unsur, yaitu: (a) AHM oil oli asli motor Honda, (b) perlindungan asli dari yang ahli. Pembagian unsur langsung dengan menggunakan teknik bagi unsur langsung dapat dibagi menjadi dua bagian, yakni: (a) AHM oil oli asli motor Honda, bermakna bahwa ahm oil merupakan oli asli dari motor Honda, (b) perlindungan asli dari yang ahli, bermakna bahwa perlindungan dapat doperoleh langsung dari yang ahli. Jadi, pembagian unsur langsung pada data kalimat teks iklan tersebut bertujuan untuk memberikan pemahaman kepada pembaca bahwa produk ahm oil merupakan oli asli dari ahm atau astra Honda motor, dan akan mendapatkan perlindungan khusus dari ahlinya.

\section{Pospay (D18/27/Mei/21)}

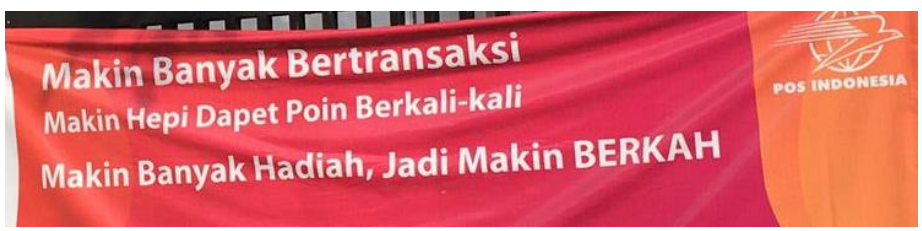

Gambar 8. Iklan Pospay

Kalimat dari data teks iklan di atas dapat dibagi menjadi dua unsur, yaitu: (a) makin banyak bertransaksi makin hepi dapet poin berkali-kali, (b) makin banyak hadiah jadi makin berkah. Dengan menggunakan teknik bagi unsur langsung, pada kalimat data teks iklan tersebut dibagi menjadi dua bagian, yaitu: (a) makin banyak bertransaksi makin hepi dapet poin berkali-kali, bermakna bahwa dapat memberikan informasi kepada pembaca untuk terus melakukan transaksi atau bertransaksi dan membuat pembaca semakin bahagia karena mendapatkan poin berkali-kali, (b) makin banyak hadiah jadi makin berkah, bermakna bahwa selain mendapatkan poin juga akan mendapatkan hadiah. Jadi, pembagian unsur langsung tersebut bertujuan untuk memberikan pemahaman atau informasi bagi pembaca untuk menggunakan jasa layanan tersebut, dengan menggunakan untuk bertransaksi secara terus-menerus maka akan banyak keuntungan yang didapat. Teks iklan tersebut merupakan jenis teks iklan perniagaan.

\section{Safi (D20/29/Mei/21)}

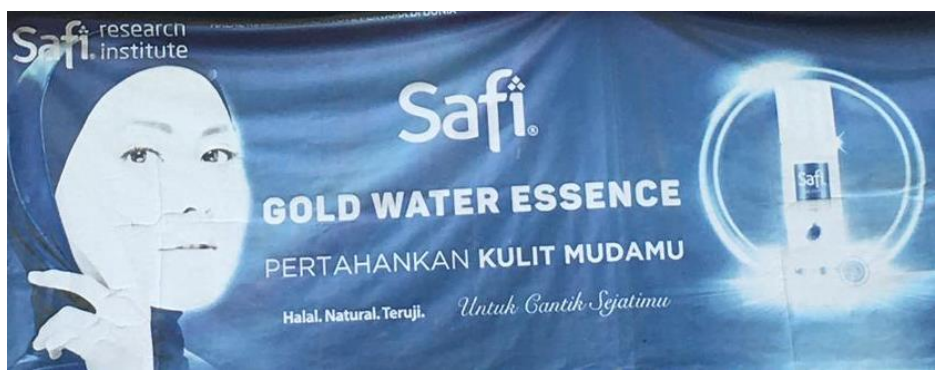

Gambar 9. Iklan Safi 


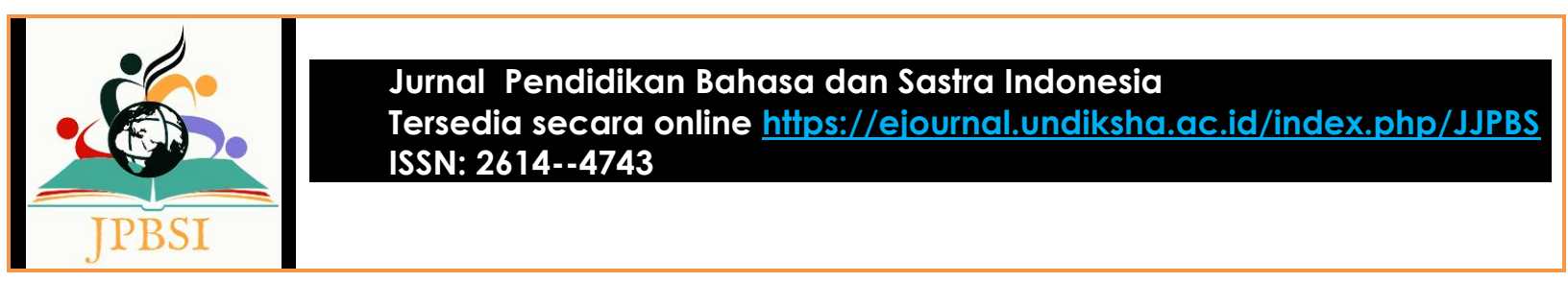

Kalimat dari data teks iklan di atas dapat dibagi menjadi dua unsur, yakni: (a) safi, (b) pertahankan kulit mudamu. Kalimat tersebut tidak tidak bisa dibagi menjadi (a) safi pertahankan, (b) kulit mudamu. Dengan menggunakan teknik bagi unsur langsung pada kalimat data teks iklan tersebut dapat dibagi menjadi dua bagian, yaitu: (a) safi, yang berarti nama produk tersebut, pemiliki produk tersebut menamai produknya dengan nama safi, (b) pertahankan kulit mudamu, bermakna bahwa meyakinkan pembaca bahwa safi dapat mempertahankan kulit muda pembaca, atau tetap menjaga kulit pembaca agar tetap terlihat muda. Kalimat di atas termasuk jenis laras bahasa perniagaan.

\section{Biru (D21/01/Juni/21)}

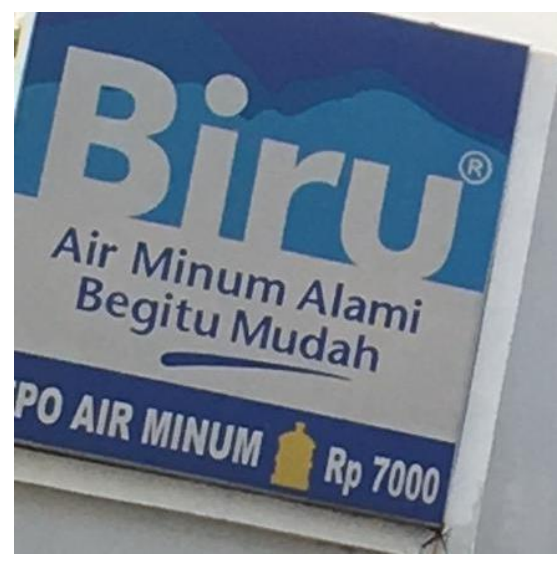

Gambar 10. Iklan Biru

Kalimat pada data teks iklan di atas dapat dibagi menjadi tiga unsur, yaitu: (a) biru, (b) air minum alami, (c) begitu mudah. Kalimat tersebut tidak dapat dibagi menjadi (a) biru air, (b) minum alami begitu, (c) mudah. Pembagian unsur langsung pada kalimat data teks iklan tersebut dapat dibagi menjadi tiga bagian, yaitu: (a) biru, yang berarti nama produk tersebut pemiliki perusahaan menamai produknya dengan nama Biru, (b) air minum alami, berarti bahwa air minum biru merupakan air minum alami maksudnya yaitu air minum yang berasal dari alam, seperti pegununangan dan lain sebagainya, (c) begitu mudah, yang produk air minum tersebut dapat dengan mudah untuk didapatkan sehingga pembaca langsung mengerti maksud dan tujuan dari penulisan teks iklan tersebut. Jadi, pembagian unsur langsung teks iklan tersebut bertujuan untuk memberikan pemahaman kepada pembaca mengenai produk air minum yang diambil langsung dari alam dan dengan mudah untuk didapatkannya yaitu air minum Biru.

\section{Ekonomi (D22/02/Juni/21)}

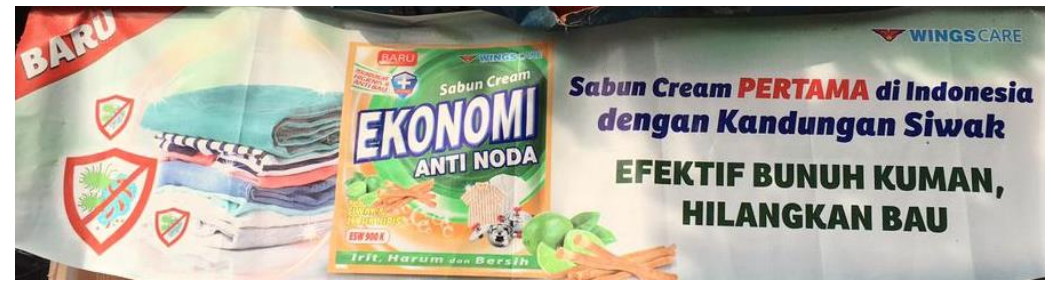

Gambar 11. Iklan Ekonomi

Kalimat data dari teks iklan di atas dapat dibagi menjadi empat unsur, yakni: (a) ekonomi, (b) sabun cream pertama di Indonesia dengan kandungan siwak, (c) efektif bunuh kuman, dan, (d) hilangkan bau. Kalimat tersebut tidak dapat diubah menjadi bagian (a) ekonomi sabun, (b) cream pertama di Indonesia dengan, (c) kandungan siwak efektif, (d) bunuh kuman dan hilangkan bau. 


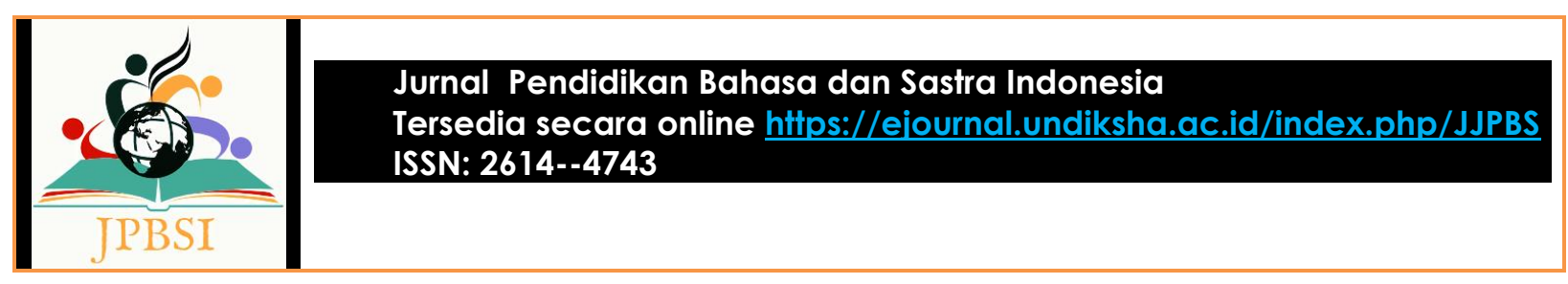

Dengan teknik bagi unsur langsung pada kalimat data teks iklan tersebut dapat dibagi menjadi empat bagian, yaitu: (a) ekonomi, yang berarti nama produk. Pemiliki produk tersebut menamai produknya dengan nama ekonomi, (b) sabun cream pertama di Indonesia dengan kandungan siwak, yang berarti bahwa sabun cream ekonomi merupakan sabun pertama yang ada di Indonesia dengan terdapatnya kandungan siwak di dalamnya, (c) efektif bunuh kuman, yang berarti bahwa sabun cream tersebut dapat dengan mudah dan tuntas bunuh kuman sehingga dapat menjaga kesehatan kulit pembaca yang segera bertindak untuk membelinya, (d) hilangkan bau, yang berarti bahwa selain dapat membunuh kuman, sabun cream ekonomi dapat menghilangkan bau tidak sedap dari pakaian, dan barang lainnya yang menggunakan sabun cream sebagai pencucinya.

Pembahasan hasil penelitian ini yaitu menunjukkan fungsi yang terkandung pada iklan produk dan jasa media luar ruang didominasi oleh fungsi informatif yang mengacu pada makna bahasa yang digunakan pada iklan media luar ruang, fungsi informatif yaitu digunakan bertujuan untuk menginformasikan sesuatu hal atau data dengan cara mendeskripsikan, melaporkan, dan menjelaskan. Hal ini sejalan dengan pendapat Hallday (dalam Sumarlam, 2003: 2) menyebutkan bahwa fungsi ini dengan istilah fungsi representatif dan pemerian. Kajian pada artikel ini keseluruhan data hasil penelitian teks iklan jasa yang menawarkan pelayanan dari data berupa iklan produk dan jasa yaitu termasuk ke dalam laras bahasa perniagaan, yaitu merupakan laras yang dapat mempengaruhi pengguna untuk melakukan sebuah tindakan setelah membaca. Hanya ada satu laras bahas bahasa perniagaan karena iklan termasuk ke dalam laras bahasa perniagaan. Pada urutan kata teks iklan terdapat dua frasa dan 7 klausa. Dengan perbedaan makna yang disebabkan oleh urutan kata. Pada urutan kalimat terdapat fungsi subjek, predikat, objek, keterangan tempat dari masing-masing data yang diperoleh. Bagian terakhir yaitu fungsi laras bahasa dari data di atas terdapat 2 fungsi direktif yang berarti memperkuat dorongan kebutuhan dan keinginan konsumen terhadap suatu produk dan jasa untuk mencapai pemenuhan kepuasannya. Terdapat 4 fungsi informasional yang berarti fungsi bahasa yang dapat digunakan untuk menginformasikan sesuatu, fungsi informasional dapat digunakan untuk mendeskripsikan, menjelaskan, dan menginformasikan sesuatu kepada masyarakat dalam bentuk iklan produk dan jasa. Terdapat 4 fungsi interaksional yang berarti untuk mengungkapkan, mempertahankan, dan mengakhiri komunikasi antara penutur dan lawan tutur. Yang terakhir terdapat 1 fungsi puitik yang berarti unsur seni ditonjolkan dalam penggunaan ritme dan rima sehingga dapat menarik perhatian konsumen dan dapat menimbulkan keinginan untuk membeli produk dan menggunakan jasa yang ditawarkan.

\section{PENUTUP}

Hasil penelitian yang dilakukan dengan ini dapat disimpulkan bahwa analisis kesalahan berbahasa teks iklan produk dan jasa di Kota Jakarta Utara akan menghasilkan sebuah bahasa-bahasa baru dengan terdapatnya analisis temuan kesalahan berbahasa teks iklan produk dan jasa di Kota Jakarta Utara yang menghasilkan laras bahasa terdapat 10 data dokumentasi, dan 1 laras bahasa perniagaan, frasa yang ditemukan terdapat 10 pada analisis kesalahan berbahasa, ditemukan terdapat 6 klausa dan 4 fungsi direktif, 8 fungsi informatif, 4 fungsi interaksional, 1 fungsi puitik. Implikasi temuan pada penelitian ini yaitu berupa pemanfaatan hasil sebagai bahan ajar untuk siswa SMP, maka penulis membuat bahan ajar yang akan diberikan ke Sekolah Menengah Pertama kelas VIII berupa bahan ajar Handout yang sudah terdapat materi ajar dengan 4 pertemuan, 4 latihan soal beserta kunci jawaban. Dapat digunakan oleh guru sebagai acuan pedoman untuk melatih siswa dalam pembelajaran teks iklan dengan contoh nyata berupa dokumentasi yang terdapat dalam Handout. Tujuan dari diadakannya diskusi tersebut, peneliti ingin mengetahui sejauh mana manfaat hasil analisis ini dapat dimanfaatkan sebagai bahan ajar pada pembelajaran materi teks iklan. Dalam pelaksanaannya, peneliti menjelaskan terlebih dahulu mengenai materi teks iklan, slogan, dan poster. Setelah itu, peneliti mencoba untuk menampilkan beberapa gambar hasil dokumentasi spanduk, slogan, dan poster teks iklan di Kota Jakarta 


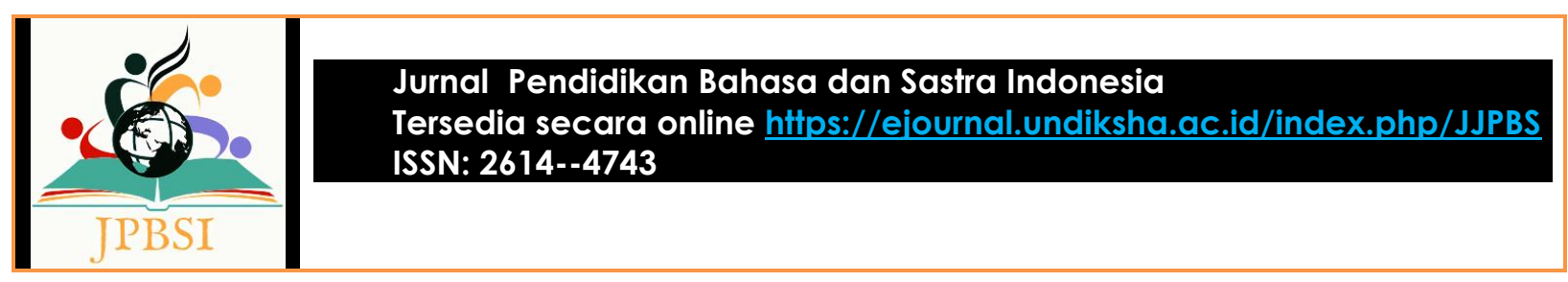

Utara yang terdapat kesalahan berbahasa kemudian menghasilkan bahasa yang sesuai antara bahasa dan penggunaannya.

\section{DAFTAR PUSTAKA}

Lexy.J. Moleong, Metodologi Penelitian Kualitatif Bandung : Remaja Roskakarya, 2000

Lofland dan Lofland dikutip oleh Dr.Lexy J Moleong, Metode Penelitian Kualitatif, bandung : Rosdakarya, 2006

Mahsun. 2005. Metode Penelitian Bahasa. Jakarta: PT Raja Grafindo Persada.

Miles, B. Mathew dan Michael Huberman. 1992. Analisis Data Kualitatif (Buku Sumber tentang Metode-metode Baru). Jakarta: UIP.

Murniati, S. (2011). Laras Bahasa Ilmiah Pada Esai Mahasiswa Polban 2011 Scientific Language Style Used in Polban Year 2011 Student' S Essays. Sigma-Mu Vol.3 No.2, 70-89.

Nursalim. (2014). Iklan dan Implikasinya dalam Pendidikan. Khutubkhanah: Jurnal Penelitian Sosial Keagamaan, 17(02), 255-264.

Pramesti, A. P., \& Martutik. (2020). Laras Bahasa Iklan pada Media Sosial Instagram. BASINDO: Jurnal Kajian Bahasa, Sastra Indonesia, Dan Pembelajarannya, 4(1), 1-16.

Pranowo. (2017). Teori Belajar Bahasa. Yogyakarta: Pustaka Pelajar.

Rahman, Taufiqur. (2017). Teks dalam Kajian Struktur dan Kebahasaan. Semarang: CV. Pilar Nusantara.

Ruhimat, Toto. Dkk. 2011. Kurikulum Dan Pembelajaran. Jakarta: PT Grafindo Persada.

Sugiyono. 2013. Metode Penelitian Pendidikan: Pendekatan Kuantitatif, Kualitatif, dan R\&D. Bandung: Alfabeta.

Sugiyono.2015. Metode Penelitian Pendidikan. Bandung: Alfabeta.

Sumarlam. 2003. Teori dan Praktik Analisis Wacana. Surakarta: Pustaka Cakra

Wresniati, S. (1997). Sekilas Tentang Laras Bahasa Media Massa Cetak. Media Litbangkes, VII (03), 33-36. 